\title{
APBA2 wt Allele
}

National Cancer Institute

\section{Source}

National Cancer Institute. APBA2 wt Allele. NCI Thesaurus. Code C104845.

Human APBA2 wild-type allele is located within 15q11-q12 and is approximately $281 \mathrm{~kb}$ in length. This allele, which encodes amyloid beta A4 precursor protein-binding family A member 2 protein, is involved in both amyloid beta A4 precursor protein processing and vesicle transport. 